\title{
Facile access to amidoethyl-p-benzoquinones
}

\author{
Mariam Al Azani, ${ }^{1}$ Nuha al Soom, ${ }^{1}$ Jesus Iniesta, ${ }^{2}$ Thies Thiemann ${ }^{1 *}$ \\ ${ }^{1}$ Department of Chemistry, United Arab Emirates University, PO Box 15551, Al Ain, Abu \\ Dhabi, United Arab Emirates; e-mail: thies@uaeu.ac.ae; thiesthiemann@yahoo.de \\ 2Institute of Electrochemistry and Department of Physical Chemistry, University of Alicante, \\ Apartado 99, E-03080 Alicante, Spain
}

\begin{abstract}
Amidoethyl-p-benzoquinones are easily accessible from 2,5-dimethoxybenzaldehyde. A one-step Wittig-hydrolysis reaction is followed by an amidation of the produced 2,5dimethoxycinnamic acid. Hydrogenation and oxidative demethylation complete the sequence to the respective amidoethyl-p-benzoquinones.
\end{abstract}

Keywords: p-benzoquinones, oxidative demethylation, amides

Introduction: A number of molecules carrying a quinone substructural unit such as a $p$ benzoquinone moiety have been found to be of medicinal value [1]. Synthetic molecules that have been synthesized in this regard include amino acid - quinone hybrids [2-4], steroid-quinone hybrids [5-9] and tacrine-quinone hybrids as potential Alzheimer disease drugs [10,11]. Saccharide - quinone hybrids have found application in the electrosensing of carbohydrate binding proteins such as lectins [12]. In our endeavor to synthesize estradiol derived $p$ benzoquinone-steroid hybrids of type 1-3 (Fig. 1), access to p-benzoquinone tethered biomolecules through a synthetic pathway utilizing reactions commonly performed in our laboratory was sought for. Here, a quick synthesis of amidoethyl-p-benzoquinones is shown that can be generally utilized to attach, after manipulation, a carbonylethyl-p-benzoquinone fragment to a molecule containing an amino or hydroxyl terminal group. 


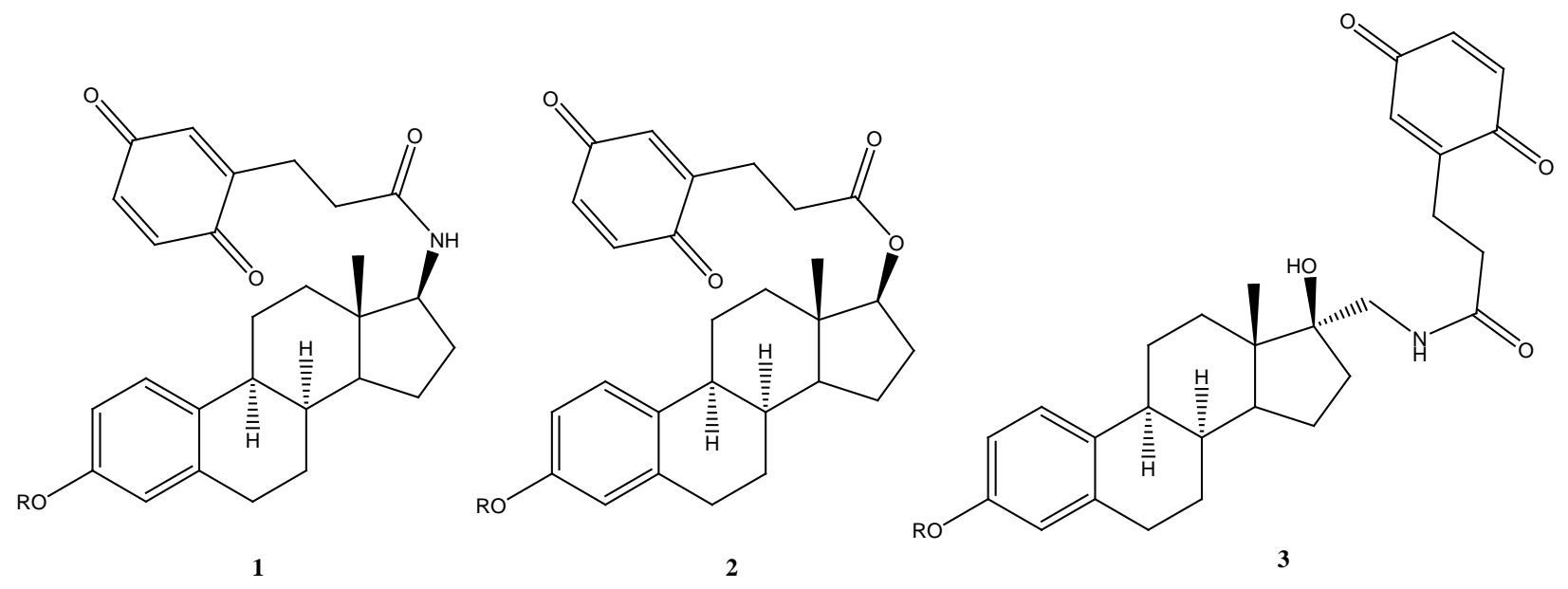

Figure 1. Steroidal quinone target molecules

\section{Experimental:}

General. - Melting points were measured on a Stuart SMP 10 melting point apparatus and are uncorrected. Infrared spectra were measured with a Thermo/Nicolet Nexus 470 FT-IR ESP Spectrometer. ${ }^{1} \mathrm{H}$ and ${ }^{13} \mathrm{C}$ NMR spectra were recorded with a Varian 400 NMR $\left({ }^{1} \mathrm{H}\right.$ at 395.7 $\mathrm{MHz},{ }^{13} \mathrm{C}$ at $\left.100.5 \mathrm{MHz}\right)$ and a Varian $200 \mathrm{MHz}$ NMR spectrometer $\left({ }^{1} \mathrm{H}\right.$ at $200.0 \mathrm{MHz},{ }^{13} \mathrm{C}$ at $50.3 \mathrm{MHz}$ ). The chemical shifts are relative to TMS (solvent $\mathrm{CDCl}_{3}$, unless otherwise noted). Mass spectra were measured with a JMS-01-SG-2 spectrometer. CHN-analysis was performed on a LECO TruSpec Micro instrument. Column chromatography was carried out on silica gel (60 A, 230 - 400 mesh, Sigma-Aldrich). Analytical thin layer chromatography (TLC) was carried out on silica on TLC Alu foils from Fluka (with fluorescent indicator at $\lambda=254 \mathrm{~nm}$ ).

$\mathrm{N}$-Octyl 3-(1,4-dimethoxyphen-2-yl)propionamide (8a). To a solution of triphenylphosphine ( $\left.\mathrm{PPh}_{3}, 960 \mathrm{mg}, 3.66 \mathrm{mmol}\right)$ in dry $\mathrm{CH}_{2} \mathrm{Cl}_{2}(15 \mathrm{~mL})$ was added dropwise bromotrichloromethane $\left(\mathrm{BrCCl}_{3}, 765 \mathrm{mg}, 3.91 \mathrm{mmol}\right)$. The resulting solution was stirred at rt for $35 \mathrm{~min}$. Then, 2,5dimethoxyphenylpropionic acid (7, $503 \mathrm{mg}, 2.40 \mathrm{mmol}$ ) was added, and the resulting mixture was stirred under reflux for $45 \mathrm{~min}$. Thereafter, $n$-octylamine (680 mg, $5.27 \mathrm{mmol}$ ) was added via syringe. The mixture was stirred under reflux for $14 \mathrm{~h}$. The cooled reaction mixture was subjected directly to column chromatography on silica gel $\left(\mathrm{CH}_{2} \mathrm{Cl}_{2}\right)$ to give $\mathbf{8 a}(465 \mathrm{mg}, 61 \%)$ as a colorless solid, mp. $63-64{ }^{\circ} \mathrm{C} ; v_{\max }\left(\mathrm{KBr} / \mathrm{cm}^{-1}\right) 3325(\mathrm{NH}), 2999,2959,2923,2852,1641$, 
1533, 1504, 1469, 1220, 1047, 852, 807, 696; $\delta_{\mathrm{H}}\left(400 \mathrm{MHz}, \mathrm{CDCl}_{3}\right) 0.87\left(3 \mathrm{H}, \mathrm{t},{ }^{3} \mathrm{~J}=6.8 \mathrm{~Hz}\right.$, $\left.\mathrm{CH}_{3}\right), 1.20-1.29$ (10H, m), $1.37-1.44$ (2H, m), 2.45 (2H, t, $\left.{ }^{3} J=7.2 \mathrm{~Hz}\right), 2.90\left(2 \mathrm{H}, \mathrm{t},{ }^{3} J=7.2\right.$ $\mathrm{Hz}), 3.18\left(2 \mathrm{H}, \mathrm{bq},{ }^{3} J=6.4 \mathrm{~Hz}, \mathrm{NCH}_{2}\right), 3.73\left(3 \mathrm{H}, \mathrm{s}, \mathrm{OCH}_{3}\right), 3.76\left(3 \mathrm{H}, \mathrm{s}, \mathrm{OCH}_{3}\right), 6.69\left(1 \mathrm{H}, \mathrm{dd},{ }^{3} J\right.$ $\left.=8.8 \mathrm{~Hz},{ }^{4} J=3.2 \mathrm{~Hz}\right), 6.73\left(1 \mathrm{H}, \mathrm{d},{ }^{4} J=3.2 \mathrm{~Hz}\right), 6.76\left(1 \mathrm{H}, \mathrm{d},{ }^{3} J=8.8 \mathrm{~Hz}\right) ; \delta_{\mathrm{C}}(67.8 \mathrm{MHz}$, $\left.\mathrm{CDCl}_{3}\right) 14.1\left(\mathrm{CH}_{3}\right), 22.6\left(\mathrm{CH}_{2}\right), 26.7\left(\mathrm{CH}_{2}\right), 26.9\left(\mathrm{CH}_{2}\right), 29.2\left(\mathrm{CH}_{2}\right), 29.2(5)\left(\mathrm{CH}_{2}\right), 29.6$ $\left(\mathrm{CH}_{2}\right), 31.8\left(\mathrm{CH}_{2}\right), 36.9\left(\mathrm{CH}_{2}\right), 39.6\left(\mathrm{CH}_{2}\right), 55.6\left(\mathrm{OCH}_{3}\right), 55.8\left(\mathrm{OCH}_{3}\right), 111.3(\mathrm{CH}), 111.7$ (CH), $116.2(\mathrm{CH}), 130.2\left(\mathrm{C}_{\text {quat }}\right), 151.4\left(\mathrm{C}_{\text {quat }}\right), 153.5\left(\mathrm{C}_{\text {quat }}\right), 172.4\left(\mathrm{C}_{\text {quat }}, \mathrm{CO}\right)$; MS (FAB) 322 $\left(\mathrm{MH}^{+}\right)$.

$N$-Octylcarboxamidoethyl-p-benzoquinone (10a). - To 8a (442 mg, $1.32 \mathrm{mmol}$ ) in acetonitrile (15 mL) was added dropwise and at rt and within 15 min. a solution of CAN (2.23 g, 8.14 mmol) in $\mathrm{H}_{2} \mathrm{O}(15 \mathrm{~mL})$. The resulting mixture was stirred for an additional $5 \mathrm{~min}$. at rt. Thereafter, water was added and the mixture was extracted with $\mathrm{CH}_{2} \mathrm{Cl}_{2}(3 \mathrm{X} 15 \mathrm{~mL})$. The combined organic phase was dried over anhydrous $\mathrm{MgSO}_{4}$ and concentrated in vacuo. The residue was subjected to chromatographic separation on silica gel $\left(\mathrm{CH}_{2} \mathrm{Cl}_{2} / \mathrm{Et}_{2} \mathrm{O}\right.$ 8:2) to give 10a (206 mg, 51\%) as a yellow solid, mp. $111-113{ }^{\circ} \mathrm{C} ; v_{\max }\left(\mathrm{KBr} / \mathrm{cm}^{-1}\right) 3331$ (vs, NH), 3052, 2954, 2924, 2851, 1655 (CO), 1537, 1427, 1311, 1131, 921, 837, 427; $\delta_{\mathrm{H}}\left(400 \mathrm{MHz}, \mathrm{CDCl}_{3}\right) 0.81\left(3 \mathrm{H}, \mathrm{t},{ }^{3} J=\right.$ $\left.6.8 \mathrm{~Hz}, \mathrm{CH}_{3}\right), 1.19-1.22(10 \mathrm{H}, \mathrm{m}), 1.37-1.42(2 \mathrm{H}, \mathrm{m}), 2.34\left(2 \mathrm{H}, \mathrm{t},{ }^{3} \mathrm{~J}=7.6 \mathrm{~Hz}\right), 2.71(2 \mathrm{H}, \mathrm{dt}$, $\left.{ }^{3} J=7.6 \mathrm{~Hz},{ }^{4} J=1.6 \mathrm{~Hz}\right), 3.16\left(2 \mathrm{H}, \mathrm{dt},{ }^{3} J=7.2 \mathrm{~Hz}, \mathrm{~J}=7.2 \mathrm{~Hz}\right), 5.53$ (1H, bs, NH), $6.55-6.56$ $(1 \mathrm{H}, \mathrm{m}), 6.65\left(1 \mathrm{H}, \mathrm{dd},{ }^{3} \mathrm{~J}=10.0 \mathrm{~Hz},{ }^{4} \mathrm{~J}=2.4 \mathrm{~Hz}\right), 6.70\left(1 \mathrm{H}, \mathrm{d},{ }^{3} \mathrm{~J}=10.0 \mathrm{~Hz}\right) ; \delta_{\mathrm{c}}(67.8 \mathrm{MHz}$, $\left.\mathrm{CDCl}_{3}\right) 14.1\left(\mathrm{CH}_{3}\right), 22.6\left(\mathrm{CH}_{2}\right), 25.3\left(\mathrm{CH}_{2}\right), 26.9\left(\mathrm{CH}_{2}\right), 29.1\left(\mathrm{CH}_{2}\right), 29.2\left(\mathrm{CH}_{2}\right), 29.6\left(\mathrm{CH}_{2}\right)$, $31.8\left(\mathrm{CH}_{2}\right), 34.3\left(\mathrm{CH}_{2}\right), 39.7\left(\mathrm{CH}_{2}\right), 133.1(\mathrm{CH}), 136.4(\mathrm{CH}), 136.7(\mathrm{CH}), 147.8\left(\mathrm{C}_{\text {quat }}\right), 170.7$ $\left(\mathrm{C}_{\text {quat }}, \underline{\mathrm{CONH}}\right), 187.4\left(\mathrm{C}_{\text {quat }}, \mathrm{CO}\right), 187.5\left(\mathrm{C}_{\text {quat }}, \mathrm{CO}\right)$; $\mathrm{MS}(\mathrm{FAB}) 292\left(\mathrm{MH}^{+}\right)$.

Results and Discussion: In the present work, the idea is to produce quinones linked to a further substructure through an amido group, using 2,5-dimethoxycinnamic acid and 2,5dimethoxyphenylpropionic acid $\mathbf{C}$ as building blocks, where the para-dimethoxyaryl function would be oxidatively demethylated to furnish the quinone moiety [13,14]. In principle, the strategy should also hold in the synthesis of quinones linked to another substructure via an ester group (Scheme 1). 
<smiles>[R][X]C(=O)CCC1=CC(=O)C=CC1=O</smiles>

A

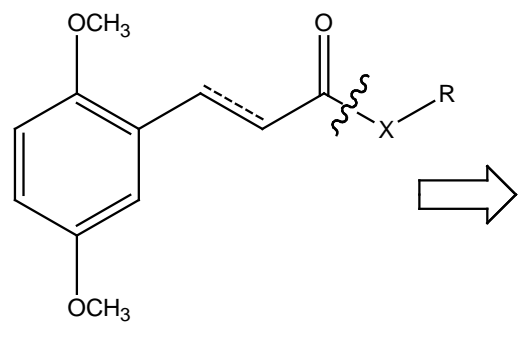

B

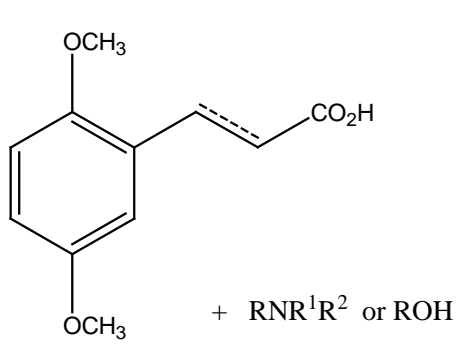

C

D

Scheme 1. Retrosynthetic analysis of amidoethyl-p-benzoquinones and their corresponding ester derivatives

2,5-Dimethoxycinnamic acid (6) can easily be synthesized via Wittig reaction from the commercially available 2,5-dimethoxybenzaldehyde (4) with subsequent hydrolysis. The two reactions can be performed in one-pot [15] (Scheme 2). 2,5-Dimethoxyphenylpropionic acid can be obtained by hydrogenation of 2,5-dimethoxycinnamic acid using a $\mathrm{H}_{2} / \mathrm{Pd}-\mathrm{C} /$ methanol reaction system [16]. As this procedure has led to a laboratory fire, the authors have changed to a hydrogenation procedure using $\mathrm{NaBH}_{4} / \mathrm{AcOH} / \mathrm{Pd}-\mathrm{C} /$ toluene [17-19]. As cinnamic acids are not well soluble in toluene, THF was added as a cosolvent in the hydrogenation of 2,5dimethoxycinnamic acid. The addition of THF seems to slightly reduce the reactivity of the Pd catalyst, perhaps through complexation to Pd (Scheme 3), so that longer reaction times are necessary.

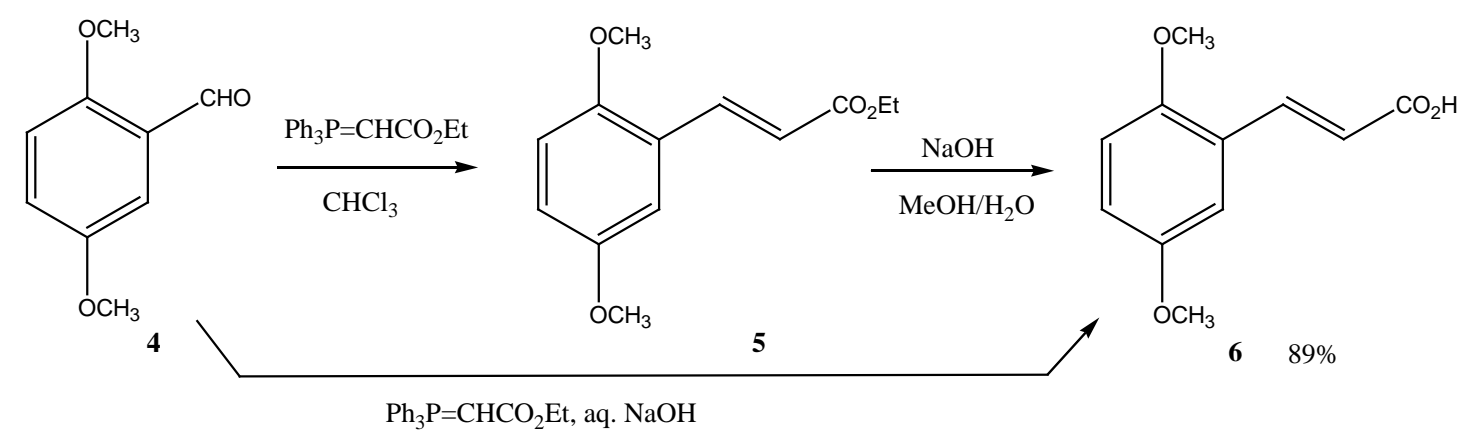

Scheme 2. Synthesis of 2,5-dimethoxycinnamic acid 

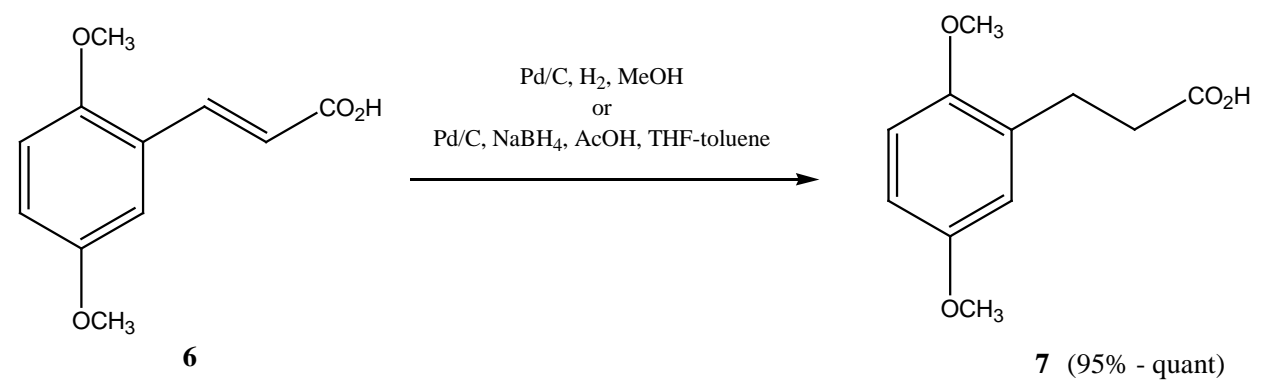

Scheme 3. Hydrogenation of 2,5-dimethoxycinnamic acid

To continue to intermediates B (Scheme 1), an amidation of 7 can be carried out (Scheme 4). Alternatively, an amidation of cinnamic acid $\mathbf{6}$ can be performed with a subsequent hydrogenation (Scheme 5). Both pathways have been pursued. As the amides are soluble in toluene, the route of amidation followed by hydrogenation circumvents the slow hydrogenation reaction of the 2,5-dimethoxycinnamic acid (6). The amidation itself is an Appel type reaction where ozone 1 depletor $\mathrm{CCl}_{4}$ has been exchanged for the less problematic $\mathrm{BrCCl}_{3}[20,21]$ (Scheme 4). The cinnamides can easily be hydrogenated to the phenylpropionamides using the reaction system $\mathrm{NaBH}_{4} / \mathrm{AcOH} / \mathrm{Pd}-\mathrm{C} /$ toluene (Scheme 5).
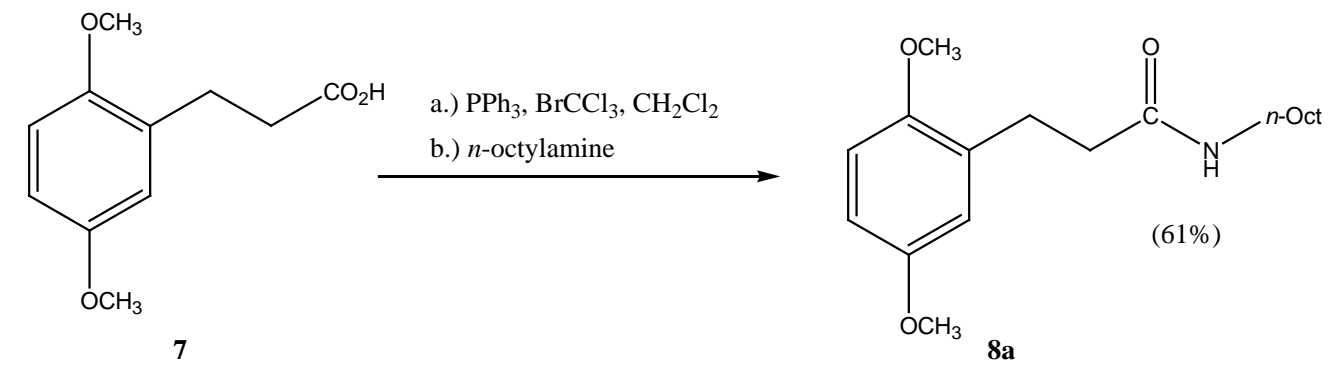

Scheme 4. Appel type amidation using $\mathrm{PPh}_{3} / \mathrm{BrCCl}_{3}$ as reagent 

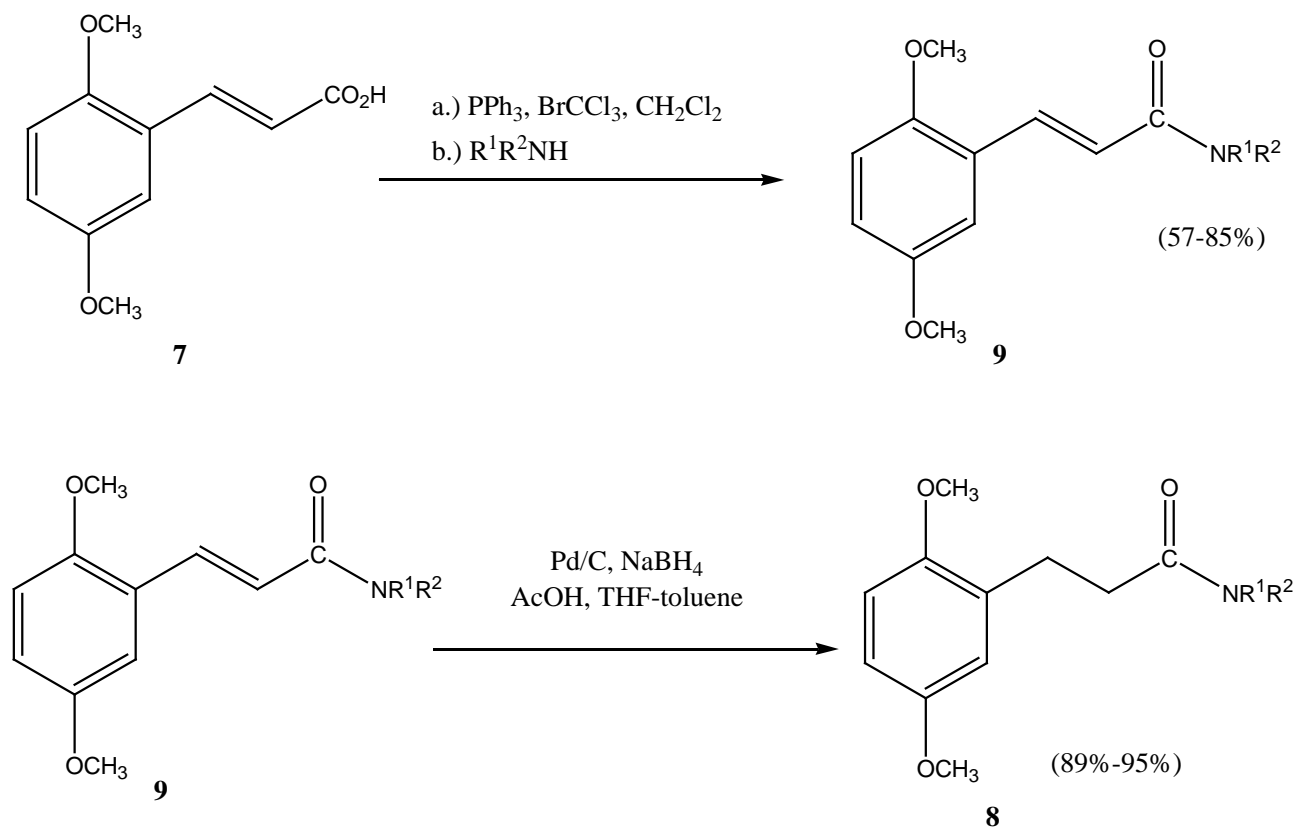

8b: $\mathrm{R}^{1}-\mathrm{R}^{2}=-\left(\mathrm{CH}_{2}\right)_{5}^{-}$ 8c: $\mathrm{R}^{1}-\mathrm{R}^{2}=-\left(\mathrm{CH}_{2}\right)_{4}$ 8d: $\mathrm{R}^{1}=\mathrm{H} ; \mathrm{R}^{2}=\mathrm{CH}_{2} \mathrm{Ph}$ 8e: $\mathrm{R}^{1}=\mathrm{R}^{2}=$ 2-ethylhexyl 8f: $\mathrm{R}^{1}=\mathrm{R}^{2}=n$-propyl

Scheme 5. Preparation of 2,5-dimethoxyphenylpropionamides

The conversion of the dimethoxyphenylpropionamides $\mathbf{8}$ to quinones $\mathbf{1 0}$ was achieved by oxidative demethylation reaction with cerium ammonium nitrate (CAN) in a solvent mixture of acetonitrile and water (Table 1). The reaction completes quickly, but led to an additional product that is stable in air for a relatively short time and has not been isolated in pure form and identified. The quinones were separated from this by-product and purified without problems by column chromatography and were acquired as pale-yellow to orange solids in the case of the secondary amides and as orange to reddish oils in case of the tertiary amides. Both carbonyl functions of the quinones invariably show a peak in the range of $\delta 187.0-188.0 \mathrm{ppm}$ in the ${ }^{13} \mathrm{C}$ NMR spectrum.

The process of Appel type reaction with 2,5-dimethoxycinnamic acid (7) using $\mathrm{PPh}_{3} / \mathrm{BrCCl}_{3}$ as the reagent, hydrogenation of the Appel-type product using $\mathrm{NaBH}_{4}-\mathrm{AcOH}-\mathrm{THF}$-toluene and subsequent oxidative demethylation with $\mathrm{CAN}$ in $\mathrm{AcCN}-\mathrm{H}_{2} \mathrm{O}$ can also be used nicely to prepare quinones bound to a substructure by ester linkage as shown in Scheme 6. 


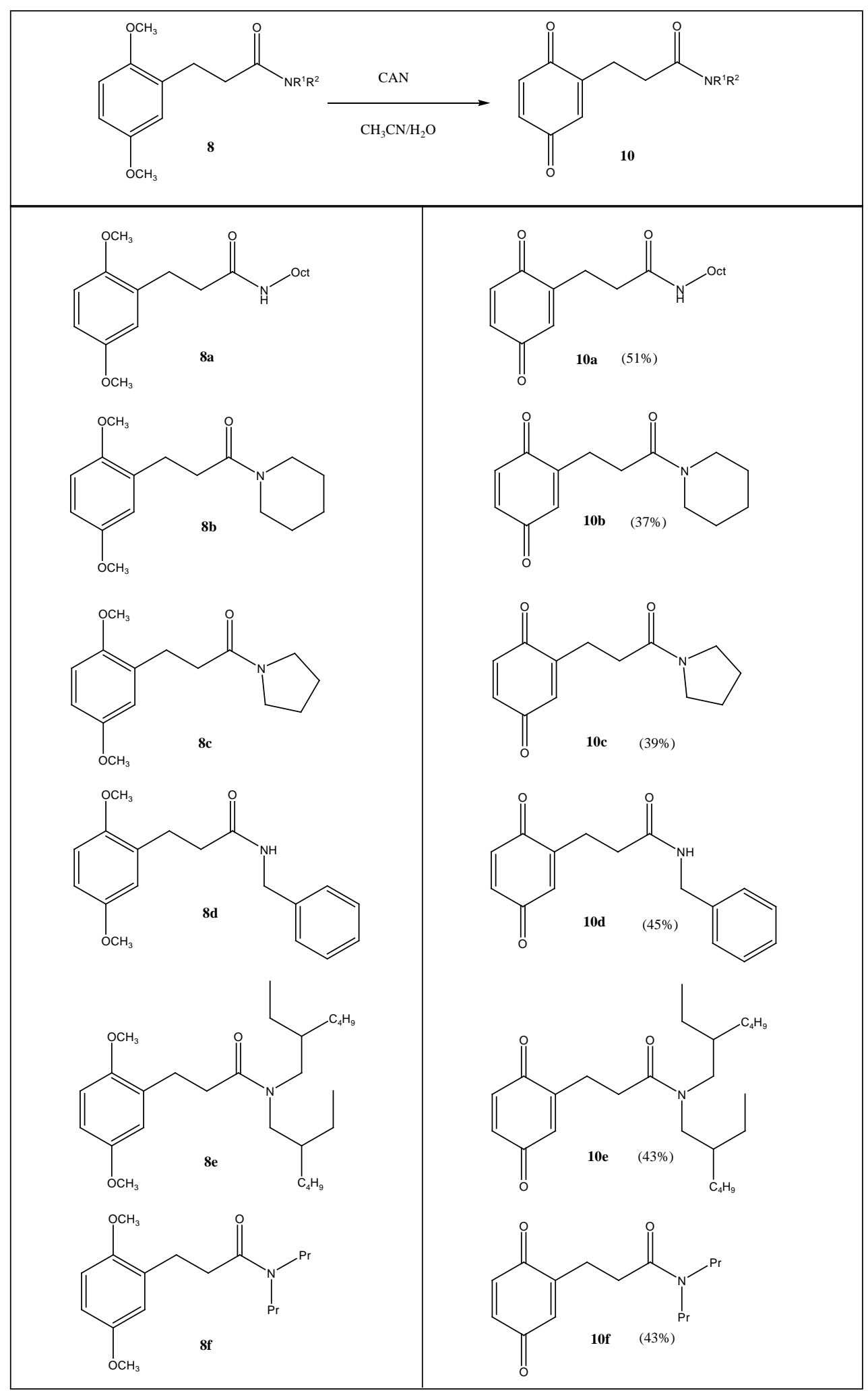

Table 1. Preparation of amidoethylquinones $\mathbf{1 0}$ 

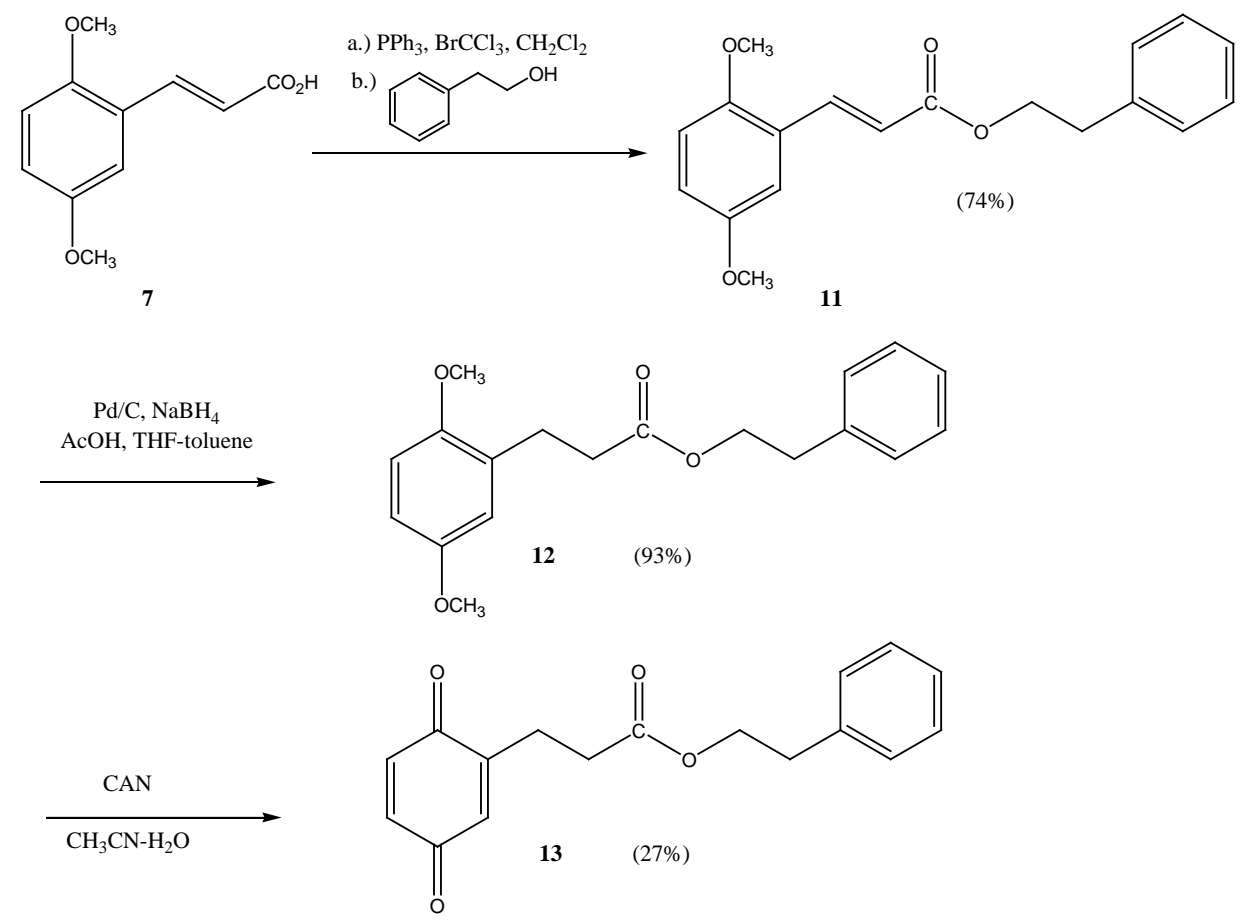

Scheme 6. Preparation of quinone-ester 13

In conclusion, a facile access to amidoethylquinones $\mathbf{1 0}$ and to quinone-ester $\mathbf{1 3}$ via an Appel type amidation/esterfication of 2,5-dimethoxycinnamic acid (7), hydrogenation of the Appel product and subsequent oxidative demethylation was shown. It is expected that the same sequence is applicable with a hydroxyl or amino containing natural product derived substructure. Efforts to obtain molecules 1-3 through a slightly modified sequence are underway.

\section{References:}

1. P. R. Dandawate, A. C. Vyas, S. B. Padhye, M. W. Singh, J. B. Baruah, Mini-Rev. Med. Chem., 2010, 10, 436 - 454.

2. P. R. Kumar, M. Behera, M. Sambaiah, V. Kandula, N. Payili, A. J. Shree, S. Yennam, J. Amino Acids, 2014: http://www.hindawi.com/journals/jaa/2014/721291/

3. R. Scherzer-Attali, D. Farfara, I. Cooper, A. Levin, T. Ben-Romano, D. Trudler, M. Vientrov, R. Shaltiel-Karyo, D. E. Shalev, N. Segev-Amzaleg, E. Gazit, D. Segal, D. Frenkel, Neurobiol. Dis., 2012, 46, 663 - 672. 
4. R. Scherzer-Attali, R. Shaltiel-Karyo, Y. H. Adalist, D. Segal, E. Gazit, Proteins, 2012, 80, $1962-1973$.

5. R. N. Hanson, US Pat. 2012/0046461 (Feb 23 $\left.{ }^{\text {rd }}, 2012\right)$.

6. R. N. Hanson, E. Hua, D. Labaree, R. B. Hochberg, K. Proffitt, J. M. Essigmann, R. G. Croy, Org. Biomol. Chem., 2012, 10, 8501 - 8508.

7. K.-L. Dao, R. P. Sawant, J. A. Hendricks, V. Ronga, V. P. Torchilin, R. N. Hanson, Bioconjug. Chem., 2012, 23, 785 - 795.

8. F. de Riccardis, D. di Meo, I. Izzo, M. di Filippo, A. Casapullo, Eur. J. Org. Chem., 1998, $1965-1970$.

9. F. de Riaccardis, I. Izzo, M. di Filippo, G. Sodano, F. d’Aquisto, R. Carnuccio, Tetrahedron, 1997, 53, $10871-10882$.

10. E. Nepovimova, E. Uliassi, J. Korabecny, L. E. Peňa-Altamira, S. Samez, A. Pesaresi, G. E. Garcia, M. Bartolini, V. Andrisano, C. Bergamini, R. Fato, D. Lamba, M. Roberti, K. Kuca, B. Monti, M. L. Bolognesi, J. Med. Chem., 2014, 57, 8567 - 8589.

11. E. Nepovimova, Design and synthesis of tacrine-quinone hybrids as multi-target ligands against Alzheimer’s disease, Diploma thesis, Charles University Prague, 2013.

12. B.-W. Zhu, L. Cai, X.-P. He, G.-R. Chen, Y.-T. Long, Chem. Central J., 2014, 8, 67.

13. P. Jacob, P. S. Calley, A. T. Shulgin, N. Castagnoli, J. Org. Chem., 1976, 41, 3627 3629.

14. M. al Azani, M. al Sulaibi, T. Thiemann, M. Montiel, C. Sánchez, J. Iniesta, Synthesis and Electrochemical Redox Properties of Arylated p-Benzoquinones, Naphthoquinones and Alkylamidoalkyl-p-Benzoquinones. In Proceedings of the 17th Int. Electron. Conf. Synth. Org. Chem., 1-30 November 2013; Sciforum Electronic Conference Series, Vol. 17, 2013, a014; doi:10.3390/ecsoc-17-a014.

15. T. Thiemann, M. W. Elshorbagy, M. H. F. A. Salem, M. A. M. al Sulaibi, B. al Hindawi, One pot reactions of benzaldehydes to cinnamic acids and arylpropiolic acids in aqueous medium. In Proceedings of the $14^{\text {th }}$ Int. Electron. Conf. Synth. Org. Chem., 1-30 November 2010; SciForum Electronic Conference Series, Vol. 14, 2010, a032; https://www.usc.es/congresos/ecsoc/14/hall_a_GOS/a032/index.pdf. 
16. B. Bugenhagen, Y. Al Jasem, M. AlAzani, T. Thiemann, Acta Cryst., Sect. E, 2015, 71, o337-o338.

17. A.T. Russo, K.L. Amezcua, V.A. Huynh, Z.M. Rousslang, D.B. Cordes, Tetrahedron Lett., 2011, 52, 6823 - 6826.

18. A. T. Tran, V. A. Huynh, E. M. Friz, S. K. Whitney, D. B. Cordes, Tetrahedron Lett., 2009, 50, 1817-1819.

19. N. al Soom, T. Thiemann, $\mathrm{NaBH}_{4}, \mathrm{CH}_{3} \mathrm{CO}_{2} \mathrm{H}, \mathrm{Pd} / \mathrm{C}$ as a reagent system to hydrogenate activated alkenes without $O$-or $N$-debenzylation, contribution submitted to ECSOC-19.

20. T. Thiemann, M. al Sulaibi, Y. Al Jasem, B. al Hindawi, Replacement of tetrachloromethane with bromotrichloromethane in Appel-type reactions, In Proceedings of the $15^{\text {th }}$ Int. Electron. Conf. Synth. Org. Chem., 1-30 November 2011; SciForum Electronic Conference Series, Vol. 15, 2011, a-002; sciforum.net/conference/ecsoc15/paper/674/download/pdf.

21. M. Al Azani, M. al Sulaibi, N. al Soom, Y. al Jasem, B. Bugenhagen, B. al Hindawi, T. Thiemann, submitted to Compt. Rend. Chim. 